Diabetologia 11, 273-278 (1975)

(C) by Springer-Verlag 1975

\title{
Glucocorticoids and the Fate of Exogenous Insulin in Insulin-Immunized Guinea Pigs
}

\author{
P.H. Wright, R.L. Gingerich, and J.R. Oliver \\ Dept. of Pharmacology, Indiana University School of Medicine, Indianapolis, Indiana, USA
}

Received: December 23, 1974, and in revised form: April 22, 1975

\begin{abstract}
Summary. Groups of normal rats and of normal and insulin-immunized guinea pigs were injected intravasculary with mixtures of radio-iodinated and unlabelled porcine insulins. No differences could be discerned between the fates of radio-iodinated and unlabelled insulins in normal or immune guinea pigs except with respect to the kidneys of normal animals, which seemed to accumulate TCA-precipitable radioactive substances devoid of immunoreactivity. The abnormally slow disappearance of insulin from the plasma
\end{abstract}

and its persistent accumulation in the livers and spleens of immune guinea pigs were not affected by prior treatment for three days with large daily doses (ca $20 \mathrm{mg} / \mathrm{kg}$ body wt.) of hydrocortisone acetate.

Key words: Insulin injection, insulin recovery, tissue insulin concentration, insulin immunized guinea pigs, hydrocortisone acetate.
We have previously shown [3] that the fate of radio-iodinated porcine insulin injected into normal animals differs markedly from that found in insulinimmunized guinea pigs. In brief, TCA-precipitable radioactive material, presumed to represent unchanged hormone, concentrates transiently in the liver and kidneys of normal animals, butdisappears more slowly from the plasma of insulin-immunized animals to accumulate more persistently and to a greater extent in their livers and spleens. In view of convincing evidence that heavily iodinated and biologically inactive insulin is not metabolized by normal rats either as rapidly or in the same manner as lightly labelled and biologically active hormone [4], the fates of commercially labelled and unlabelled insulins were compared in normal and immune guinea pigs. The influence of hydrocortisone acetate upon the fate of insulin in immune guinea pigs was also studied, since glucocorticoids have been shown to have the most consistent beneficial effects upon insulin resistance seen in some human diabetic patients [9]. The results show that very similar results can be obtained with the labelled and unlabelled hormones, and that pretreatment of immune guinea pigs with large doses of hydrocortisone does not appear to have any effect upon the fate of subsequently injected insulin.

\section{Materials and Methods}

\section{Animals}

Male albino guinea pigs (body wts., 0.83 to 1.64 $\mathrm{kg}$ ) were either normal or had been immunized over a period of 8 to 9 months with porcine insulin by a standard method [13]. Levels of insulin-binding antibodies in the sera of these guinea pigs were estimated by the method of Makulu and Wright [5]. In an additional experiment, male albino rats (body wts., 178 to $216 \mathrm{~g}$ ) were used. All animals had free access to food and water up to the time of intravascular insulin injection.

\section{Intravascular Inocula}

These consisted of mixtures of radio-iodinated and unlabelled porcine insulins dissolved in solutions of either normal or anti-insulin sera from guinea pigs. The ${ }^{125} \mathrm{I}$-labelled (ca $100 \mu \mathrm{C} / \mathrm{ml}, 0.8$ to $0.9 \mu \mathrm{g}$ insulin/ $\mathrm{ml}$; Cambridge Nuclear Corporation, Billerica, Mass.) and ${ }^{131} \mathrm{I}$-labelled (ca $130 \mu \mathrm{C} / \mathrm{ml}, 0.65 \mu \mathrm{g}$ insulin $/ \mathrm{ml}$; Abbott Laboratories, North Chicago, Mlinois) porcine insulins were used within three days of receipt after appropriate dilution. No attempt was made to purify 
further these samples of labelled hormone. Unlabelled porcine insulin (Lot Nos. PJ4489, 21.1U/mg, and PJ5682, 23.9 U/mg; Eli Lilly and Company, Indianapolis, Indiana) was dissolved in dilute acetic acid $(0.6 \%$ glacial, $\mathrm{v} / \mathrm{v})$, the stock solution $(100 \mathrm{U} / \mathrm{ml})$ being stored at $4{ }^{\circ} \mathrm{C}$ for later dilution immediately before use. These hormones were initially diluted in relatively small volumes of a buffered solution $\left(\mathrm{Na}_{2} \mathrm{H}-\right.$ $\mathrm{PO}_{4} / \mathrm{KH}_{2} \mathrm{PO}_{4}, 0.05 \mathrm{M}, \mathrm{pH} 7.0$ ) containing sodium chloride $(0.4 \%, \mathrm{w} / \mathrm{v})$ and normal guinea pig serum (NGPS; $3 \%, \mathrm{v} / \mathrm{v}$ ); this buffered solution is here termed $3 \%$ NGPS. Final dilution of the hormones was carried out in relatively larger volumes of undiluted normal guinea pig serum (NGPS) or guinea pig antiinsulin serum (GPAIS). The GPAIS used for the experiment in rats (Lot No. 555, binding 1.53 Units porcine insulin $/ \mathrm{ml}$ ) was allowed to react with the insulin for $30 \mathrm{~min}$ at $36{ }^{\circ} \mathrm{C}$ before it was injected. The precise compositions of inocula are given below with the results.

\section{Experimental Procedures}

Some animals were treated with hydrocortisone (Hydrocortone acetate, saline suspension; Merck, Sharpe and Dohme, West Point, PA) for 3 days before injection of insulin. Both rats ( $5 \mathrm{mg} /$ day) and guinea pigs $(20 \mathrm{mg} /$ day $)$ received relatively large subcutaneous doses.

Labelled and unlabelled insulins which had previously been incubated with GPAIS were injected intravenously (tail vein) into rats which were killed 30 min later by decapitation. Guinea pigs, whether normal or immune, were all given an antihistamine (Chlorpheniramine maleate, $10 \mathrm{mg}$; Chlortrimeton maleate, Schering Corporation, Bloomfield, N.J.) by subcutaneous injection, were then lightly anesthetized with ether and given the insulin inoculum $(0.5 \mathrm{ml})$ by intracardiac injection; approximately 10 min elapsed between the two injections. No immune guinea pig was seen to develop signs of any acute allergic reaction; without prior treatment with an antihistamine, death occurs within a few minutes with signs of severe respiratory distress [12]. Guinea pigs were killed by decapitation 5 to $60 \mathrm{~min}$ after intracardiac injection.

After decapitation, blood was collected from the severed necks into heparinized beakers and the plasma rapidly separated by centrifugation. If not used immediately, plasma samples were stored in the frozen state at $-10^{\circ} \mathrm{C}$. The liver, kidneys and spleen of each animal (unless otherwise stated) were rapidly removed from the body and weighed. Weighed portions of each, as indicated under the heading "Results", were then homogenized or extracted, initial handling, precipitation or extraction being complete within 2 min:

a) Tissue Homogenates. Weighed portions (ca 1.0 g) of liver and kidney were added to ice-cooled distilled water $(10 \mathrm{ml})$ and homogenized (Polytron, Kinematica GMBH, Lucerne, Switzerland). Smaller portions were used for the spleens. The gamma-radioactive contents of aliquots $(0.5 \mathrm{ml})$ of these homogenates were measured in an automatic well-type scintillation counter (Series 300, Model 5052, Packard Instrument Company, LaGrange, Illinois) either (i) without further treatment (Total radioactive content) or (ii) after precipitation of proteins with an equal volume $(0.5 \mathrm{ml})$ of trichloracetic acid (TCA, 20\%, w/v) and subsequent washing of the precipitate with more dilute $(10 \%, w / v)$ TCA (TCA-precipitable radioactive content). Plasma $(1.0 \mathrm{ml})$ was diluted in distilled water $(10 \mathrm{ml})$ and then treated in the same way as the homogenates. The radioactive contents of these precipitates, solutions and homogenates are here expressed with respect to the wet wt. $(\mathrm{g})$ or volume $(\mathrm{ml})$ of tissue.

b) Acid-Alcohol Extraction. Plasma $(1.0 \mathrm{ml})$ or weighed aliquots (ca. $1.0 \mathrm{~g}$ ) of liver or kidney were added to an ice-cooled solution $(10 \mathrm{ml})$ of acid-alcohol $(2.1 \%, \mathrm{v} / \mathrm{v}$, concentrated sulfuric acid in $80 \%, \mathrm{v} / \mathrm{v}$, aqueous ethanol). The tissue was homogenized and the suspensions allowed to stand at $4^{\circ} \mathrm{C}$ for 2 days. Precipitates were separated by centrifugation and an aliquot $(1.0 \mathrm{ml})$ of the clear supernatant solution neutralized with a saturated solution of sodium bicarbonate $(0.7 \mathrm{ml})$; the final $\mathrm{pH}$ of this solution was usually between 7.0 and 7.5. The insulin contents of these neutralized extracts, after removal of precipitates, were immediately determined using small aliquots $(0.05 \mathrm{ml})$ and standard solutions of porcine insulin dissolved in the same neutralized solution of acid alcohol. The method of insulin immuno-assay in which ${ }^{125}$ I-labelled and unlabelled porcine insulins were used, has been described elsewhere [14]. Immunoreactive contents were related to the wet wts. (g) or volumes (ml) of tissue.

For experiments in which only the fate of the labelled hormone was to be studied, ${ }^{125}$ I-labelled porcine insulin was injected. When the fates of both labelled and unlabelled insulins were to be followed, ${ }^{131}$ I-labelled porcine insulin was injected so that ${ }^{125} \mathrm{I}$-labelled insulin could be used subsequently for the assay of immunoreactive insulin in tissue extracts. Separate pieces of the same tissue were used for assays of radioactive and immunoreactive contents. This was done to speed initial processing of the tissues and so reduced the possibility of insulin destruction by enzymes in those tissues.

Unless otherwise stated, all values are given as the 
Table 1. Fates of unlabelled and iodinated insulins in normal and insulin-immunized guinea pigs. Mean concentrations ( \pm SEM) of TCA-precipitable radioactivity and of immuno-reactive insulin in tissue homogenates and extracts are shown for 5 to 7 normal and insulin-immunized guinea pigs killed 5 and $30 \mathrm{~min}$ after intracardiac injection of mixture of ${ }^{131}$ I-labelled $(1.0 \mathrm{mU})$ and unlabelled $(1.0 \mathrm{U})$ porcine insulins. Other experimental details are given in the text

\begin{tabular}{|c|c|c|c|c|}
\hline Guinea pig status: & Normal & & Immune & \\
\hline $\begin{array}{l}\text { Killed (minutes } \\
\text { after injection) }\end{array}$ & 5 & 30 & 5 & 30 \\
\hline Number of animals & 5 & 5 & 5 & 7 \\
\hline \multicolumn{5}{|l|}{ Mean weights: } \\
\hline Body (kg) & $1.28 \pm 0.04$ & $1.33 \pm 0.08$ & $1.35 \pm 0.09$ & $1.39 \pm 0.05$ \\
\hline Liver (g) & $29.9 \pm 0.7$ & $34.8 \pm 1.7$ & $36.6 \pm 3.4$ & $32.8 \pm 1.2$ \\
\hline Kidney $(\mathrm{g})$ & $8.5 \pm 0.6$ & $8.9 \pm 0.9$ & $6.5 \pm 0.6$ & $6.7 \pm 0.3$ \\
\hline Spleen $(\mathrm{g})$ & $0.80 \pm 0.04$ & $1.01 \pm 0.16$ & $1.25 \pm 0.07$ & $1.26 \pm 0.16$ \\
\hline \multicolumn{5}{|c|}{ Concentration of radioactivity ( $\mathrm{cpm} \times 10^{-3} / \mathrm{g}$, wet wt. or $\mathrm{ml}$ tissue) } \\
\hline Plasma & $34.2 \pm 2.2$ & $14.9 \pm 1.5$ & $66.7 \pm 4.7$ & $30.1 \pm 2.8$ \\
\hline Liver & $15.7 \pm 1.0$ & $8.2 \pm 0.9$ & $48.7 \pm 7.2$ & $76.9 \pm 6.6$ \\
\hline Kidneys & $49.6 \pm 6.2$ & $36.0 \pm 3.3$ & $3.4 \pm 0.2$ & $1.7 \pm 0.2$ \\
\hline Spleen & $5.4 \pm 0.5$ & $2.7 \pm 0.8$ & $17.6 \pm 2.2$ & $27.7 \pm 4.4$ \\
\hline \multicolumn{5}{|c|}{ Concentration of immunoreactive insulin (mU/g. wet wt. or $\mathrm{ml}$ tissue) } \\
\hline Plasma & $5.74 \pm 0.92$ & $2.58 \pm 0.76$ & $12.10 \pm 0.85$ & $6.53 \pm 0.99$ \\
\hline Liver & $2.63 \pm 0.45$ & $1.64 \pm 0.83$ & $7.93 \pm 0.65$ & $11.67 \pm 1.10$ \\
\hline Kidneys & $10.47 \pm 1.13$ & $2.65 \pm 1.01$ & $2.56 \pm 0.94$ & $2.37 \pm 0.88$ \\
\hline
\end{tabular}

means $( \pm$ SEM), differences between mean values being considered significant at or below the $5 \%$ level of probability. All statistical analyses were carried out according to methods described by Snedecor and Cochran [10].

\section{Results}

\section{Fates of ${ }^{131} I$-Labelled and of Unlabelled Porcine Insu- lins in Normal and Immune Guinea Pigs}

An inoculum $(0.5 \mathrm{ml})$ containing ${ }^{131}$ I-labelled (1.1 $\mathrm{mU})$ and unlabelled(1.0U) porcine insulins, dissolved in a mixture of $3 \%$ NGPS $(0.17 \mathrm{ml})$ and undiluted NGPS $(0.33 \mathrm{ml})$, was injected into four groups of 5 or 7 normal or immune guinea pigs which were killed 5 or $30 \mathrm{~min}$ later. Details concerning the animals used and of the concentrations of TCA-precipitable radioactivity and of immunoreactive insulin found in their tissues are given in Table 1.

In normal guinea pigs the concentrations of TCAprecipitable radioactivity fell by about half between 5 and $30 \mathrm{~min}$ in the plasma, liver and spleen, and by about one quarter in the kidneys. Only in the kidneys, at both 5 and $30 \mathrm{~min}$, did the concentration of radioactivity exceed that in the plasma. In insulin-immunized guinea pigs, on the other hand, concentrations of TCA-precipitable radioactivity decreased more slowly in the plasma but increased by almost $50 \%$ in both the livers and spleens between 5 and $30 \mathrm{~min}$. Very little radioactivity was recovered at either time from the kidneys of these immune animals. After 30 min the mean concentration of radioactivity in the livers exceeded and that in the spleens equalled levels found in plasma.

A similar, but not identical, pattern of distribution of injected immunoreactive hormone was observed in these same animals. Thus in normal guinea pigs the concentrations of recovered immunoreactive insulin fell by about half between 5 and $30 \mathrm{~min}$ in the plasma and livers, but in immune guinea pigs it accumulated in the livers as it disappeared more slowly from the plasma. In these two tissues, plasma and liver, whether removed after 5 or $30 \mathrm{~min}$ from normal or immune animals, the ratios of recovered immunoreactivity to TCA-precipitable radioactivity $(\mathrm{mU} / 100 \mathrm{cpm})$ were constant. Thus the ratios in normal animals for plasma at $5(0.177 \pm 0.031)$ and $30(0.237 \pm 0.055) \mathrm{min}$ and in immune animals at $5(0.182 \pm 0.007)$ and 30 $(0.216 \pm 0.028) \mathrm{min}$ were not significantly different from one another; this was also true of liversfrom these same four groups of animals. The mean ratio for all these plasma samples $(0.201 \pm 0.016, n=21)$ was 
not significantly different from that calculated for the corresponding livers $(0.169 \pm 0.021, n=22)$, but both ratios were significantly lower than the observed ratio in the inoculum $(0.264 \mathrm{mU} / 100 \mathrm{cpm})$. Little immunoreactive or radioactive material was recovered from the kidneys of immune animals. Relatively high concentrations of both were found after $5 \mathrm{~min}$ in the kidneys of normal animals when the ratio $(0.218 \pm 0.022 \mathrm{mU} / 1000 \mathrm{cpm})$ was not significantly different from those quoted above for the livers and plasma. After $30 \mathrm{~min}$, however, the immunoreactive contents of the kidneys of these normal animals had fallen to a much greater extent than had their radioactive contents, the ratio $(0.096 \pm 0.023 \mathrm{mU} / 1000$ cpm) then being significantly lower than the value found after $5 \mathrm{~min}$.
Effects of Treatment with Hydrocortisone upon the Fates of Unlabelled and Iodinated Insulins in Rats and Guinea Pigs

Groups of 7 to 9 rats and guinea pigs were given daily subcutaneous injections of hydrocortisone for 3 days; control animals received no injections. The rats were then injected intravenously with insulin-antibody complexes formed by pre-incubation of ${ }^{125} \mathrm{I}-\mathrm{la}$ belled and unlabelled porcine insulins with a slight excess of GPAIS. The insulin-immunized guinea pigs, under light ether anesthesia and after administration of an antihistamine, received intracardiac injections of inoculum containing radio-iodinated and unlabelled insulin dissolved in NGPS, and were killed by decapitation 30 or 60 min later. Details of each group of

Table 2. Effects of hydrocortisone upon the fates of radio-iodinated insulin/antibody complexes in normal rats (Expt. "A") and of radio-iodinated insulin in insulin-immunized guinea pigs (Expts. "B" and "C"). Shown in the Table are the doses of glucocorticoid given, the compositions of the inocula given by intracardiac injection, and the mean concentrations and estimated recoveries of TCA-precipitable radioactivity $( \pm S E M)$ in tissues from injected rats and guinea pigs. The one value for recovered radioactivity in a tissue of corticoid-treated animals which is significantly different from the control value $(p<0.05)$ is indicated $\left(^{2}\right)$. More experimental details are given in the text

\begin{tabular}{|c|c|c|c|c|c|c|}
\hline \multirow{4}{*}{$\begin{array}{l}\text { Animals } \\
\text { Experiments } \\
\text { Hydrocortisone } \\
\text { (mg/day for } 3 \text { days) } \\
\text { Animals (n) }\end{array}$} & \multirow{2}{*}{\multicolumn{2}{|c|}{$\frac{\text { Normal rat }}{\mathrm{A}}$}} & \multicolumn{4}{|c|}{ Insulin-immunized guinea pigs } \\
\hline & & & \multicolumn{2}{|c|}{$\mathrm{B}$} & \multicolumn{2}{|c|}{$\mathrm{C}$} \\
\hline & Nil & 5 & Nil & 20 & Nil & 20 \\
\hline & 7 & 7 & 7 & 9 & 7 & 8 \\
\hline \multicolumn{7}{|l|}{ Mean weights (g): } \\
\hline Body & $206 \pm 3$ & $198 \pm 4$ & $1080 \pm 66$ & $1117 \pm 55$ & $1390 \pm 50$ & $1220 \pm 8$ \\
\hline Liver & $8.35 \pm 0.33$ & $8.85 \pm 0.24$ & $28.8 \pm 2.2$ & $36.3 \pm 1.3$ & $32.8 \pm 1.2$ & $30.7 \pm 2.6$ \\
\hline Kidney & - & - & - & - & $6.7 \pm 0.3$ & $6.1 \pm 0.4$ \\
\hline Spleen & $0.68 \pm 0.04$ & $0.67 \pm 0.07$ & $1.31 \pm 0.08$ & $1.14 \pm 0.13$ & $1.26 \pm 0.16$ & $1.45 \pm 0.20$ \\
\hline \multicolumn{7}{|l|}{ Inoculum: } \\
\hline Insulin (mU) & 1000 & 1000 & 200 & 200 & 1000 & 1000 \\
\hline I-Insulin (mU) & 0.9 & 0.9 & 2.0 & 2.0 & 1.1 & 1.1 \\
\hline Gpais (ml) & 0.96 & 0.96 & Nil & $\mathrm{Nil}$ & $\mathrm{Nil}$ & Nil \\
\hline $\begin{array}{l}\text { Killed (minutes } \\
\text { after injection) }\end{array}$ & 30 & & 60 & & 3 & \\
\hline \multicolumn{7}{|c|}{ Concentration of radioactivity $\left(\mathrm{C} \times 10^{-3} / 100 \mathrm{secs} / \mathrm{g}\right.$. wet wt. or $\mathrm{ml}$ tissue $)$} \\
\hline Plasma & $135 \pm 5$ & $146 \pm 11$ & $136 \pm 15$ & $185 \pm 38$ & $30.1 \pm 2.8$ & $35.0 \pm 3.8$ \\
\hline Liver & $353 \pm 11$ & $345 \pm 12$ & $476 \pm 47$ & $316 \pm 31^{\mathrm{a}}$ & $76.9 \pm 6.6$ & $74.3 \pm 9.0$ \\
\hline Kidney & - & - & - & - & $1.7 \pm 0.2$ & $2.4 \pm 0.2$ \\
\hline Spleen & $89 \pm 13$ & $78 \pm 7$ & $71 \pm 15$ & $93 \pm 22$ & $27.7 \pm 4.4$ & $25.3 \pm 5.6$ \\
\hline \multicolumn{7}{|c|}{ Recovered radioactivity (percentage of injected dose) } \\
\hline Plasma & $18.5 \pm 0.5$ & $19.2 \pm 1.2$ & $29.4 \pm 4.0$ & $39.2 \pm 7.9$ & $43.6 \pm 4.7$ & $44.6 \pm 5.9$ \\
\hline Liver & $45.6 \pm 1.8$ & $47.2 \pm 1.1$ & $67.6 \pm 3.9$ & $57.8 \pm 4.8$ & $66.2 \pm 3.7$ & $57.6 \pm 3.5$ \\
\hline Kidney & - & - & - & - & $0.3 \pm 0$ & $0.4 \pm 0$ \\
\hline Spleen & $0.9 \pm 0.1$ & $0.8 \pm 0.1$ & $0.5 \pm 0.1$ & $0.5 \pm 0.1$ & $0.9 \pm 0.1$ & $0.9 \pm 0.1$ \\
\hline
\end{tabular}




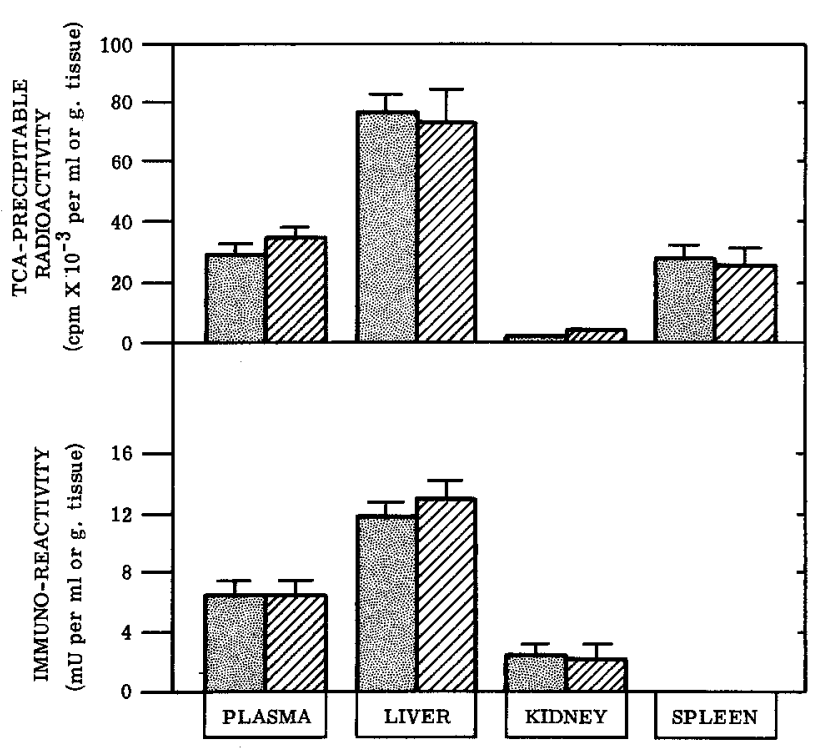

Fig. 1. TCA-precipitable radioactive and immunoreactive contents (Mean \pm SEM) of tissues removed from hydrocortisone-treated (cross-hatched) and control (stippled) insulin-immunized guinea pigs killed $30 \mathrm{~min}$ after intracardiac injection of a mixture of ${ }^{131} \mathrm{I}$ labelled $(1.1 \mathrm{mU})$ and unlabelled $(1.0 \mathrm{U})$ porcine insulins. Each column represents the mean of observations in 7 or 8 animals. Further experimental details are given in the text and were comparable with those shown in Table 2, Expt. "C"

animals, of their tratments and of the TCA-precipitable and immunoreactive contents of their tissues are shown in Table 2 and Fig. 1.

In the first experiment (A) normal rats were killed $30 \mathrm{~min}$ after injection of heterologous insulin-antibody complexes. As shown in Table 2, the mean concentrations of TCA-precipitable radioactivity found in the plasma, livers and spleens of the hydrocortisone-treated rats were not significantly different from those found in the same tissues of control animals. Based on the mean plasma volume $(4.30 \pm 0.13$ $\mathrm{ml} / 100 \mathrm{~g}$ body wt.) found in a previous study of similar rats (15) and the known weights of the organs concerned, it is also seen that total recoveries from plasma and the other tissues do not differ in the two groups.

In the second experiment (B) immune guinea pigs were killed $60 \mathrm{~min}$ after injection of a mixture of ${ }^{125}$ I-labelled and unlabelled $(200 \mathrm{mU})$ porcine insulins. Mean concentrations of TCA-precipitable radioactivity in the plasma and spleens of hydrocortisonetreated animals were not significantly different from those for the controls, but the mean concentration in livers of treated guinea pigs was significantly $(p<$ $0.025)$ and appreciably (33\%) lower than the control value. When the published value [7] for plasma volume in guinea pigs ( $3.94 \mathrm{ml} / 100 \mathrm{~g}$ body wt.) and the known weights of the various organs were used for calculations, the total recoveries from the plasma and other tissues of treated guinea pigs were not significantly different from the controls.

In the third experiment $(\mathrm{C})$ immune guinea pigs were killed $30 \mathrm{~min}$ after injection of ${ }^{131}$ I-labelled insulin mixed with the large dose $(1.0 \mathrm{U})$ of unlabelled hormone. On this occasion, no significant differences were found between the concentrations of TCA-precipitable radioactivity in the plasma, livers, spleens or kidneys of the control and hydrocortisone-treated animals; the same applied to calculated total recovery rates. Similarly, and as illustrated on Fig. 1, no distinction could be made between treated and control animals on the basis of recovered concentrations of immunoreactive insulin in these same tissues.

\section{Discussion}

Before considering possible implications of these findings, three brief comments are indicated. First, total recoveries of radioactive and immunoreactive insulin from the various tissues have been calculated on the basis of assumed plasma volumes or on the assumption that the weighed organs contained no trapped blood. As a result, for example, it is found that total recoveries of TCA-precipitable radioactivity from the plasma, livers, kidneys, and spleens of immune guinea pigs killed $5(134 \%)$ and $30(111 \%)$ min after injection (Table I) exceed $100 \%$. In the absence of specific knowledge of the plasma volumes and of the blood or plasma contents of the tissues, any calculated values for total recovery can only be considered as approximate. Secondly, the low but constant measured ratio of immunoreactive to radioactive contents of tissues removed from injected animals $(0.17-0.20$ $\mathrm{mU} / 1000 \mathrm{cpm})$ compared to that $(0.26 \mathrm{mU} / 1000$ $\mathrm{cpm}$ ) of the inoculum probably reflects a low but uniform rate of insulin recovery $(60-70 \%)$ during acid-alcohol extraction. Finally, the low ratio of immunoreactive to radioactive contents in kidneys from normal guinea pigs killed $30 \mathrm{~min}$ after injection $(0.096$ $\mathrm{mU} / 1000 \mathrm{cpm}$ ) was not further investigated. It is known, however, that iodinated insulin can retain TCA-precipitability whilst losing its immunoreactive and/or its biological functions. Thus Narahara et al. [8] could only convert 60 to $70 \%$ of the TCA-precipitable material in radio-iodinated insulin to a TCA-soluble form by incubation in vitro with liver homogenates. Similarly, Malaisse et al. [6] could only achieve about $70 \%$ conversion to TCA-soluble material by incubation of radio-iodinated insulin with pieces of pancreatic tissue. During the same time, however, ability of the labelled hormone to adsorb onto cellulose powder 
was completely lost. These latter observations suggest that the TCA-precipitable material persisting in the kidneys of normal guinea pigs (Table 1) probably includes degradation products of the hormone which have lost immunoreactivity but have retained TCAprecipitability.

The results themselves show that radio-iodinated and unlabelled exogenous insulins are utilized in vivo in much the same ways. Theyparticularly demonstrate that insulin is utilized in a markedly abnormal way by immune animals, concentrating as it does in those tissues, the liver and spleen, which contain large numbers of fixed tissue macrophages. Such an abnormal fate was also envisaged by Berson and Yalow [1] for insulin injected into human diabetic patients having high levels of circulating insulin antibodies and high requirements for insulin. They postulated that "owing to its degradation with antibody, a large fraction of the bound (injected) insulin never becomes available to the tissues." The nature of this degradation process is not known, but if it resembles that involved in the destruction of other antigen/antibody complexes then, as Berson and Yalow later suggested [2], injected insulin might be destroyed by such patients at rates of the order of 500 to 1000 Units/day. Such resistance to therapy with insulin is not common but "the adrenal steroids and ACTH," wrote Shipp et al. [9], "have most consistently altered insulin resistance;" the doses of insulin needed to maintain metabolic control often drop dramatically within a matter of days. The reason for the success of this treatment is not known, but glucocorticoids are known to influence immune processes. Vernon-Roberts [11] in a recent review has pointed out that small doses of glucocorticoids stimulate and large doses inhibit phagocytic activity in guinea pigs, rats and mice. On the assumption that phagocytosis might also be playing some part in the removal of insulin-antibody complexes from the plasma of immune guinea pigs, and that a similar phenomenon might be responsible for insulin resistance in the human diabetic, large doses of hydrocortisone were given to the present immune animals. However, as is clearly shown in Table 2 and Fig. 1, prior treatment of guinea pigs and rats for 3 days did not influence the fates of injected insulin or of insulinantibody complexes. There was a suggestion that uptake of insulin by the livers of one group of immune guinea pigs (Expt. No.B) was reduced, but this was not confirmed in the second study (Expt. No. C). It is conceivable that the experimental conditions were not ideal, that the period of treatment with cortisone was too short, or that the species of animal used here was not suitable, but the present results do not support the contention that glucocorticoids inhibit immunological destruction of exogenous insulin in the immune animal.

Acknowledgements. This investigation was supported by the U.S. Public Health Service (Grant No. PHS AM 16534-02). The authors wish to thank Eli Lilly and Company, Indianapolis, Indiana, for insulin preparations; and Mrs. Vivian Williams and Mrs. Debra Stricklin for skilled technical assistance.

\section{References}

1. Berson, S.A., Yalow, R.S.: Insulin antagonists, insulin antibodies and insulin resistance. Amer. J. Med. 25, 155-159 (1958)

2. Berson, S.A., Yalow, R.S.: The present status of insulin antagonists in plasma. Diabetes 13, 247-259 (1964)

3. Frikke, M.J., Gingerich, R.L., Stranahan, P.D., Carter, G., Bauman, A.K., Greider, M.H., Wright, P.H., Lacy, P.E.: Distribution of injected insulin and insulin-antibody complexes in normal and insulin-immunized animals. Diabetologia 10, 345-351 (1974)

4. Izzo, J.L., Bartlett, J.W., Roncone, A., Izzo, M.J., Bale, W.F.: Physiological processes and dynamics in the disposition of small and large doses of biologically active and inactive ${ }^{131} I$-insulin in the rat. J. biol. Chem. 242, 2343-2355 (1967)

5. Makulu, D.R., Wright, P.H.: Immune response to insulin in guinea pigs: some quantitative studies. Metabolism 20, 770-781 (1971)

6. Malaisse, W., Malaisse-Lagae, F., Wright, P.H.: A new method for the measurement in vitro of pancreatic insulin secretion. Endocrinology 80, 99-108 (1967)

7. Masouredis, S.P., Melcher, L.R.: Blood, plasma and "Globulin" space of guinea pigs determined with $\mathbf{I}^{131}$ rabbit globulin. Proc. Soc. exp. Biol. (N.Y.) 78, 264-266 (1951)

8. Narahara, H.T., Tomizawa, H.H., Miller, A., Williams, R.H.: Intracellular distribution of an insulin-inactivating system of liver. J. biol. Chem. 217, 675-684 (1955)

9. Shipp, J.C., Cunningham, R.W., Russell, R.O., Marble, A.: Insulin resistance: clinical features, natural course and effects of adrenal steroid treatment. Medicine (Baltimore) 44, 165-186 (1965)

10. Snedecor, G.W., Cochran, W.G.: Statistical Methods. Iowa State University Press 1967

11. Vernon-Roberts, B.: The effects of steroid hormones on macrophage activity. Int. Rev. Cytol. 25, 131-159 (1969)

12. Wright, P.H.: The effect of insulin antibodies on glucose uptake by the isolated rat diaphragm. biochem. J. 71, 633-638 (1959)

13. Wright, P.H., Makulu, D.R., Posey, I.J.: Guinea pig anti-insulin serum; adjuvant effect of $H$. pertussis vaccine. Diabetes $\mathbf{1 7}$, 513-516 (1968)

14. Wright, P.H., Makulu, D.R., Vichick, D., Sussman, K.E.: Insulin immunoassay by back-titration; some characteristics of the techniques and the insulin precipitant action of alcohol. Diabetes 20, 33-45 (1971)

15. Wright, P.H., Rivera-Calimlim, L., Malaisse, W.J.: Endogenous insulin secretion in the rat following injection of anti-insulin serum. Amer. J. Physiol. 211, 1089-1094 (1966)

P.H. Wright, M. D. Dept. of Pharmacology Indiana Univ. School of Medicine 1100 West Michigan Street Indianapolis, Indiana 46202 USA 